\title{
Current trends in Green Urbanism and peculiarities of multifunctional complexes, hotels and offices greening
}

\author{
I. S. Kosenko, V. M. Hrabovyi, O. A. Opalko, H. I. Muzyka, A. I. Opalko \\ National Dendrological Park "Sofiyivka", National Academy of Science of Ukraine Kyivska St. 12a, \\ Uman, Ukraine.
}

E-mail: ndp.sofievka@gmail.com; opalko_a@ukr.net

Received: 10.02.2020 Accepted 06.03.2020

\begin{abstract}
The analysis of domestic and world publications on the evolution of ornamental garden plants use from the ancient Egyptians, Greeks and ancient Romans to the "dark times" of the middle Ages and the subsequent Renaissance was carried out. It was made in order to understand the current trends of Green Urbanism and in particular regarding the diversity of floral and ornamental arrangements used in the design of modern interiors of public spaces. The aim of the article is to grasp current trends of Green Urbanism regarding the diversity of floral and ornamental arrangements used in the design of modern interiors of public premises. Cross-cultural comparative methods have been used, partially using the hermeneutics of old-printed texts in accordance with the modern system of scientific knowledge. The historical antecedents of ornamental gardening, horticulture, forestry and vegetable growing, new trends in the ornamental plants cultivation, modern aspects of Green Urbanism are discussed. The need for the introduction of indoor plants in the residential and office premises interiors is argued in order to create a favorable atmosphere for work and leisure. The extreme importance of selecting an assortment and developing environmentally friendly ways to increase the resistance of indoor plants against pathogens and pests in conditions of insufficient lighting, humidity, abnormal fluctuations in air temperature, etc. has been revealed. In conclusion, the world experience in the use of ornamental garden plants testifies to the eternal desire of man for unity with nature, which is especially growing in conditions of progressive urbanization. The current global trends of Green Urbanism are of particular importance in Ukraine in terms of the Ukrainian public aspirations to integrate the state into the European community.
\end{abstract}

Key words: Ancient greeks and romans; Biblical garden of Eden; Consumerism; Dark ages; Flower language; Ikebana; Indoor gardens; Ornamental horticulture

\section{Introduction}

The study of the connections between consumption levels and personal happiness provides ambiguous evidence for this dependence. It is noted that although the level of consumption, in general, has little effect on human happiness (Easterlin, 1974; McBride, 2010), however, the demonstration of excessive consumption by certain social groups representatives causes the effect of envy. It is supported by understandable negative effects on the feeling of individual happiness in a wide range of other social groups that do not have opportunities to luxuriate (Easterlin, 2015; Wang et al., 2018). When consumption becomes the goal and meaning of life, then public morality dies, and joy disappears... In a result, modern consumerism is increasingly becoming an analogue of abnormal/immoral excess consumption and a kind of harmful addiction. It is clearly manifested in shopping addiction, similar to alcoholism or drug addiction. All mentioned and similar cases are dangerous (Opalko et al., 2019), both for the individual and for society as a whole (Lipovetsky, 1993).

At the same time, every person, regardless of social status, place of residence, and profession remains a child of nature. Everyone can suddenly feel happy when they see a sunny flower of an ordinary dandelion or inhale the scent of a spring lily of the valley. Roses, lilies or gladioli, as well as many other summer plants, raise one's spirit. Special feelings are also caused by brightly burning berries of hawthorn and rose hips on a background of green pines and firs. The Christmas tree has always been completed by a variegated flower plants grown on the windowsill, the care of which gives the owners an incomparable joy. Residents of urbanized megapolicies ignore all forms of life except human life, however, on a subconscious level, they experience a constant attraction to communicate with nature and enjoy plants on city streets, in city parks and squares, as well as in the few islands of wild nature, preserved by enthusiasts in urban conditions. The increased interest in growing ornamental plants has become especially acute in recent years in the post-Soviet space, as well as the awareness of the incredible value and charm of the surrounding nature. It is a manifestation of the primordial aspirations of a person to surround himself with beauty, planting various trees, shrubs and flowers, and saturating his life with positive emotions, joy and creative energy (Opalko et al., 2019). The Green Urbanism of Western Europe that is currently being observed nowadays proves that an alternative urban future is possible if its principles are transformed from a utopia into the natural components of a person's lifestyle (Beatley, 2012).

Ornamental plantings improve the architectural appearance of cities, give them a diversity of colours, and create a threedimensional silhouette. The richness of the ornamental properties of most plants and their ability to change provide unlimited opportunities for forming the appearance of green areas of populated areas (Kolesnikov, 1974; Someh et al., 2014). To determine 
the feasibility of mass propagation of a some species (forms, cultivars) of plants, wide introduction into culture and use in landscape design, as well as for greening balconies, apartments, lobbies and offices, it is necessary to take into account not only ornamental properties, but also ecological and biological features. The manifestation of ornamental properties, ecological and biological features of each plant is determined by the interaction of its genotype with environmental factors (Dirr, 2009; Seneta \& Dolatowski, 2012), its survival in conditions that are not always optimal for the plant being grown, and its ability to preserve the ornamental qualities for the sake of attractiveness of which this plant is grown.

Criteria for the ornamentation of an individual element of landscape design (Kolesnikov, 1974), a certain species and/or cultivar of plants, as well as an individual, sometimes grown using a special technology, for example. "bonsai" (Tomlinson, 2004), diverse significantly in different climatic zones of our planet, socio-ethnic communities, and, of course, historical epochs.

For an ecologist, each plant is beautiful in its way. Changing depending on the time of year, it becomes noticeable at some point. Undoubtedly, there are very beautiful plants, but the common dandelion (Taraxacum officinale (L.) Weber ex F. H. Wigg) is also incredibly bright, although it is not in the lists of ornamental ones (Figure 1).

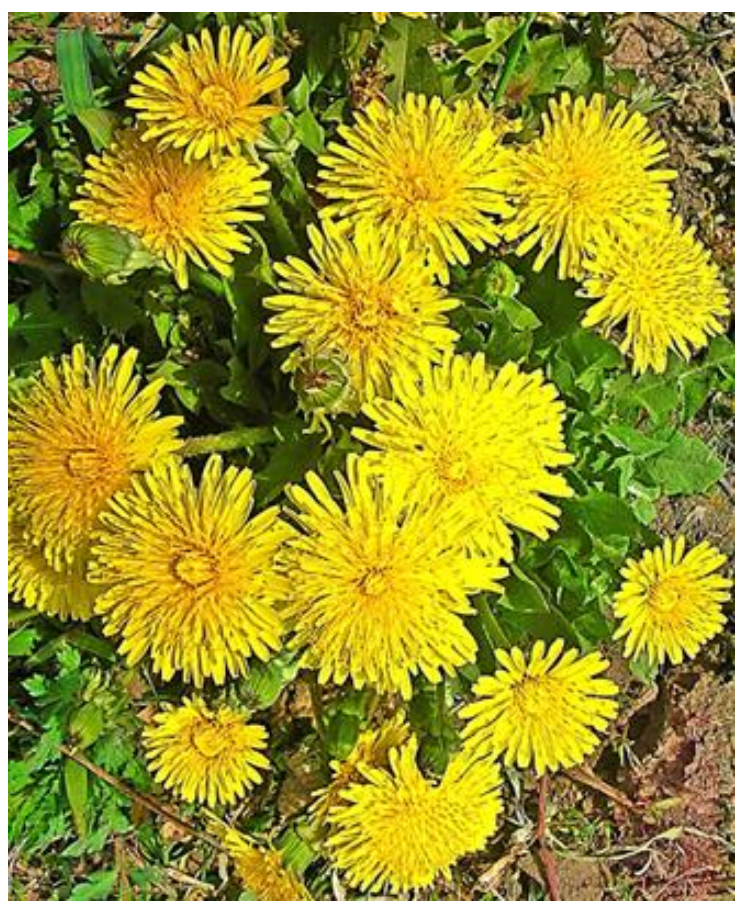

Figure 1. The flowering of dandelion (Taraxacum officinale (L.) Weber ex F.H. Wigg) (according to Opalko et al., 2019 with changes).

Quite often, the most desirable for a connoisseur of ornamental plants are considered unusual for this region's plants. They surprise and sometimes shock with their appearance, which determines the increased interest to strange plants of the botanical institutions collections (Pakhomov et al., 2008). For this very reason, many tropical plants seem attractive primarily due to their exoticism for the middle zone inhabitants. These plants are reared in greenhouses, apartments, lobbies of large campanies and hotels, in offices. Many of them are considered common ones in their tropical homeland, and no one grows them to decorate apartments or office spaces (Opalko et al., 2019).

\section{Methods}

A number of publications on the results of experimental and theoretical studies conducted by scientists of different scientific schools had been analyzed. It was done given a rich history of ornamental plants taking into account the historical aspects of the evolution of perception the value of nature, as well as the phenomenon of the rapid spread of Green Urbanism trends in Ukraine (Aristov, 1866; Baeyer, 2010; Beatley, 2012; Dirr, 2009; ElAziz et al. 2015; Farahani et al., 2016; Farrar, 2016; Gray, 2011; Grodzinskiy, 1979; Ingels, 2010; Janick, 2007, 2014; Johnson, 2010; Kirkby \& Diffenbaugh, 2011; Kubo \& Schrempp, 2006; Martin, 2009, 2015; Nonaka, 2017; Rogers \& Hiss, 2016; Thommen, 2012). While choosing materials, the group selection method was used. It allowed identifying publications by applying citation criteria in scientific peer-reviewed journals and giving preference to research conducted under international programs.

\section{Results and Discussion}

Ornamental plant cultivation has a fairly long history. At the same time, unlike grain and other food plants, it is quite difficult to reliably separate the historical antecedents of gardening from horticulture, forestry, and vegetable growing. Some current ornamental plants were previously used as food and/or forage crops. It is known that such a wonderful plant as the peach (Prunus persica (L.) Batsch), whose juicy fruits can satisfy the most refined taste, was once used for fattening pigs (Ingels, 2010). And nowadays, next to the fruit cultivars of peaches, ornamental cultivars of peaches and many other species of garden plants are cultivated. Ornamental cultivars of cherries, sweet cherries (Prunus spp.), apple trees (Malus spp.), pears (Pyrus spp.) and many other fruit plants (Gasanov et al., 2014) are successfully used in the greening of cities.

\section{Gardens of the ancient world}

Several Western cultures have adopted the biblical Garden of Eden as the ideal standard and role model for creating their gardens. Biblical and other religious texts are rich in horticultural metaphors, particularly regarding Adam 
and Eve in the garden of Eden near the tree of knowledge; description of the olive branch as a sign of peace, and Noah's cultivation of the vineyard as his first act of economic activity after the flood (Janick, 2007; Ingels, 2010).

In addition to religious texts relating to the history of gardening, there are documented records of the existence of gardens as far back as the ancient Egyptians and Sumerians more than 5,000 years ago. Despite the fact that the main goal of cultivating ancient gardens was to provide food, but it were the Egyptians who began to grow plants due to their aesthetic value (Ingels, 2010).

More than 200 species of aromatic flower plants have been identified from remains found in Egyptian royal tombs. Judging by the drawings and utilitarian ornamental plants growing in pots and tubs (Figure 2), it can be assumed that the ancient Egyptians used container gardening along with growing in gardens, at least for transporting the most valuable trees (Farrar, 2016; Opalko et al., 2019).

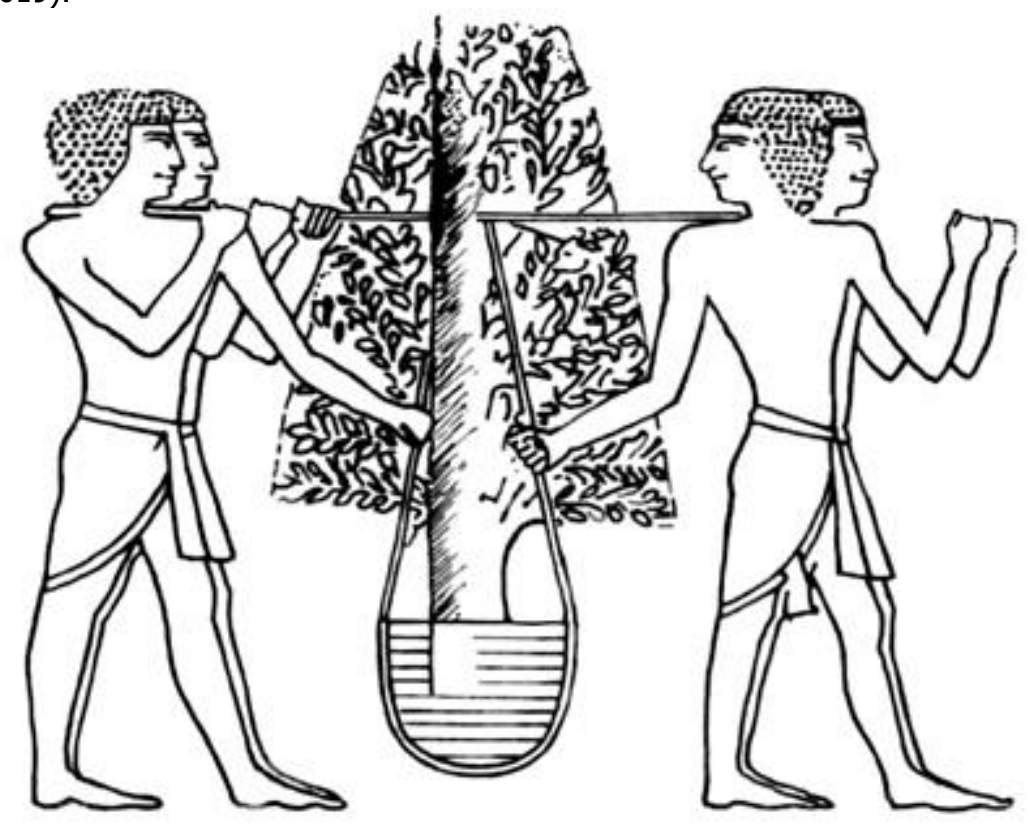

Figure 2. Incense trees transportation from Punt to Egypt, temple of Hatshepsut, Deir el-Bahari (according to Linda Farrar, 2016 with changes).

In contrast to the relatively stable rule of Egypt, the lands of Ancient Mesopotamia and the Levant underwent changes by several successive rulers starting with the Sumerians (late fourth Millennium BC). They lived in several cities in the South and on the Middle Euphrates, later conquered by the Semites, who ruled from 2400 to 2200 BC. After several wars, the Babylonians (southern Mesopotamia) and the Assyrians on the Tigris (Northern Mesopotamia) reigned on the Euphrates. Among the mighty people in those lands, we should also mention the Persians, whose powerful Empire lasted from 550 to 330 BC and covered territories from Greece and Libya to India. It is clear that their garden art has undergone much more changes over the centuries than in Egypt. At the same time, the image on the Sumerian stone seal dated to the Third Millennium BC, known as the Temptation Seal, resembles the biblical story of the Garden of Eden. A place called Edin or Eden is mentioned in Sumerian texts of those times (Farrar, 2016). In the cities of Ancient Greece, gardens and parks were also given great attention. Archaeological evidence suggests that even during the bronze age (the third-first Millennium BC), the Minoans deeply loved nature and quite often used flowers, in particular poppies and irises and terpentic trees in ornamental arrangements. On ceramic ware, we come across stylized images of rose hips, crocuses, daisies, lilies, three species of Cretan tulips, etc. (Farrar, 2016). According to historians, the fourth part of the city of Alexandria, founded in 332 BC by Alexander the Great, was under parks (Baeyer, 2010). The construction of that city was done by architect Dinokrate Rhodes for a typical Greek city heptaminol system with a rectangular-mesh scheme of urban neighborhoods. The abundance of ornamental plantings and parks, apparently, can be explained not only by Greek tradition and the great influence of ancient Egyptian culture. In general, the ancient Greek stage of ornamental gardening can be estimated as a transition between Sumerian-ancient Egyptian and ancient Roman (Ingels, 2010). The horticultural art of Ancient Greece was influenced by early horticultural concepts, such as the Persian garden model (Baeyer, 2010; Farahani et al., 2016). The Persian word that was used to name the garden was translated into Greek, and then into Latin, and has come down to us as the word "paradise" in the sense of "Paradise on earth" (Baeyer, 2010).

The Romans borrowed horticultural knowledge from the Egyptians and Greeks, and especially the Etruscans successfully used them and provided their further development, in particular, improved the grafting and budding methods. They are also practiced by current gardeners, designed garden knives, garden ladders, and many other tools for garden care. It was in Ancient Rome that the most amazing fantasies of wealthy citizens were embodied in peristyle gardens with colonnades, villa-gardens with reservoirs, sculptures, flower beds and clipped shrubs for the purpose of visual enjoyment and pleasant leisure. The ideology of Roman society was based on the desire for the ideal of man, in which both soul and body would be in harmony. There is a kind of cult of physical pleasures and enjoyment (Ingels, 2010). In those days, the garden was perceived as a space inhabited by deities, and the bias before the deities extended to nature and its man-made copies - gardens. However, it was in ancient times that the ambiguous relationship between man and nature became more acute, as a manifestation of the contradictions between the increased exploitation of natural resources and the need to preserve nature (Tommen, 2012).

After the fall of the Roman Empire, its provincial possessions were taken over by barbarian tribes. At the end of the 5th century several barbarian states were formed on the ruins of the once-powerful Empire. Ruined Roman cities fell into disrepair, the construction of temples and public buildings stopped. Barbarians did not see any value in images of people and gods, easily destroying magnificent paintings, and poured antique bronze sculptures into ingots. The only works of art that were not destroyed by the barbarians are ornate ware and various household items, as well as ornate weapons (Janick, 2014).

Agriculture in the Roman Empire at the time of its rise was at a very high level. It is natural that the barbarians who seized Rome could not accept the ancient agricultural technology. They brought extensive forms of agriculture: two-field crop rotation, and often 
even more primitive fallow, leaving for several years without finishing the depleted plot of land that was previously under arable land (in order to restore fertility). But the achievements of Roman agricultural production were discarded and soon forgotten. Harvests plummeted, and widespread famine swept through all Western European countries in the second half of the first Millennium. It is clear that a hungry person does not admire garden, park beauty, and high art. Therefore, the period of 5-14th centuries, which is a Millennium between the fall of Rome at the end of the 14th century and the Renaissance, which began with Italy in the 14th century, is usually called the Middle Ages. It is also described as a period of "oppressive dogmatism" or "dark ages". Garden and park art almost died. It is the most vulnerable of all art forms and much more than others' needs for its existence a peaceful environment. Separate plants were preserved in small gardens only in monasteries and castles, that is, in areas relatively protected from destruction. This usually kept the shape of the garden in the Roman style, but in a completely different monastic context. The column-bounded square/rectangular area of the monastic garden resembled the gardens of the classical peristyle. Such gardens can be dated as far back as 560 since within the monastic rule of Saint Isidore was already a condition to have a garden. However, these partially preserved gardens were mostly utilitarian. Later, with the development of Christian monasteries, which became plant repositories and places of improvement of European horticultural technologies, the search for ancient Greek and Roman manuscripts of herbalists and their translation began. Some monks who cultivated herbs and spices in the monastery gardens became experts in applying knowledge from ancient herbalists to treat various ailments. In the 7th century, during the reign of Saint Benedict, not only the desire for self-sufficiency within the monastic community was established throughout the West, but also the need to plant gardens where monks could retire for study or reflection (Farrar, 2016).

Between the 11th and the end of the 13th century, European cities began to revive and grow; agriculture and horticulture began to develop. It led to a revival of the desire to study and awareness of the value of knowledge itself. However, it was only in the 15th century that such gardens began to be decorated with trellis gazebos and fences, equipped with turf benches in the form of projections along the fence and small fountains (Nonaka, 2017). Many of these gardens were already intended for recreation. In the late middle Ages there was an official separation of horticulture from agriculture and forestry (Farahani et al., 2016).

However, the "dark ages" referred to the wreckage of the Western Roman Empire. But India and China were not subjected to the desolation and barbarism. Although barbarians sometimes broke through their borders, they usually settled among the more developed locals and, under the influence of the prevailing mass of native speakers, quickly assimilated with them into a single nation (Pomerantz \& Mirkin, 2012). In a result, the leaders of world history and culture in the Middle Ages, were not the Western world, but the ancient Byzantium and Eastern China. Herewith, until at least the 10th century BC, China and Japan were centers of horticultural development and innovation, isolated for centuries from other centers. This is indirectly confirmed by the archaeological findings of Chinese silk in Egypt of the 10th century BC. Garden art in the 2nd century BC in China was already quite developed. It was evidenced by documented descriptions of complex gardens with artificial hills, complex water basins, and irregular artificial rocks, as well as other elements of garden design in the form of idealized scenes from nature (Farahani et al., 2016). Ornamental gardening became part of the culture of China and spread throughout Asia with the development of the city gardens of the emperors. Flower growing became one of the seven arts and acquired a mystical significance (Janick, 2002).

Common elements of the Chinese and later Japanese formal gardens were basins/lakes, islands, bridges, waterfalls, mounds, trees, and rocks. At the same time, it is known that some new fruits and vegetables were introduced from Asia and India to China in the 6 th century $A D$. In the 12th century, it was the Chinese who built greenhouses, where the oiled paper was used for the lightpermeable housing. In such greenhouses, the Chinese successfully grew various heat-loving flowers and vegetables (Farahani et al., 2016).

As in other ancient civilizations, the early ornamental gardens of China were created mainly in the Imperial palaces, and later in the estates of the wealthy and the high-placed. The visits of Marco Polo, as well as the activities of Arab traders, contributed to the spread of Chinese horticultural technologies and plants in Europe. This borrowing was intensified, starting from 900 AD, along the trade route of the famous Great Silk Road caravans. The design of ornamental gardens in Japan was formed directly under the influence of Chinese models. However, the Japanese garden that appeared later than the 3rd century was more abstract than the Chinese garden. The first Japanese manual on garden art "Sakuteiki, or Records on Garden Making" (Takei \& Keane, 2001), appeared in the early 13th century (Farahani et al., 2016).

Gardening developed also in pre-Columbian America. The gardens of the Aztec nobles were sacred places filled not with food, but with ornamental, aromatic, and medicinal plants that symbolized various gods and myths about them. Food crops for the nobles were grown by members of the lower classes in separate specialized gardens. The great Aztec leader Montezuma generally forbade the cultivation of edible plants in his gardens, pointing out that they should only be grown in the gardens of the lower classes and delivered to his table as a tribute. But the flowers had been cultivated in the gardens of the courtiers because they were very important in Aztec religious rituals. All believed that the flowers were given by the gods to the leaders in confirmation of their right to rule. Spanish documents from the 12th and 13th centuries show that Aztec Botanical gardens were filled with wild species organized in a Botanical system (Baeyer, 2010).

Old Russian gardening began in the 11th century in the Kyiv-Pechersk monastery under Abbot Theodosius. Sources of the 14th century revealed Moscow gardens, but with a very poor assortment. The Italian traveler Giosafat Barbaro (1413-1494), who visited Moscow in 1439, wrote that there were practically no fruits in the city, except for "a small number of apples, nuts, and hazel-nuts" (Aristov, 1866). Flowers were the main attribute of one of the old Slavic June holidays - Green holidays or Spirit Day (Opalko et al., 2019). The belief that every plant on Green holidays has a sacred meaning dates back to pre-Christian times.

\section{Use of cut flowers in water-filled containers, of immortelles \& artificial flowers}

No one knows exactly when and to whom flowers were given for the first time as a sign of love, sympathy or respect. It is also unknown where and when the first cut flowers were brought into the room to enjoy their beauty. However, both archaeologists and art historians are convinced that cut flowers in water-filled containers gave aesthetic pleasure to a man in the days of early civilizations. It has been proved that the ancient Egyptians used plant material in religious and possibly other ceremonies to create flower arrangements for more than two and a half thousand years BC (Belcher, 1998; Bowler, 2016).

Carved reliefs and wall paintings found by archaeologists indicate that in those ancient times cut flowers were placed in vases made of glass or terracotta ceramics. Many of these vases had several spouts for individual flowers. This style of making vases and arranging bouquets was later adopted by florists in Persia and the Netherlands. The rules for forming arrangements from cut flowers were apparently quite strict since there were few variations of their images over the centuries. In addition to the Lotus, which was considered as sacred flower, the herbage, palm trees, and papyrus were often used, as well as blue snowdrops, irises, 
anemones, and narcissus (Belcher, 1998; McDonald, 2018). The sacred symbolism of the Lotus is still preserved. Its cut flowers and water lilies are now sold mainly in religious places in Asia (Yakandawala, 2016).

In the ancient Greek and Roman periods, cut flowers were also given an equally important role, but the flowers and leaves were often used without containers of water. Floral wreaths and garlands were made to decorate the columns. They were carried on wands and used to crown winning athletes, public leaders, and other important people. In the days of Nero and Cleopatra, rose petals were scattered on floors, streets, decorative lakes, and festive tables. It was the Romans who developed the technology of out-of-season forcing blooms out of roses in a room. Hot water pipes were used to heat them. They decorated their luxury feasts with such roses (Belcher, 1998).

In medieval times, monks grew many useful plants outside the monastery walls. These were mainly plants for food or medicinal purposes. Sometimes plants were used to decorate church altars, but very few flowers were bred just for beauty. Chinese artifacts show that cut flowers placed in water-filled containers were used on temple altars as early as the Tang dynasty (618-906 AD). Paintings on silk, parchment scrolls, and vases, embroidery and carvings of ivory, bronze, and wood from that period indicate the early use of plants for aesthetic purposes. The Chinese highly valued flowers and ornamental greenery. Bonzes (Buddhist priests) instilled in them high respect for all living things, so they cut plants very sparingly and used a minimum number of cut flowers in their arrangements. The only exception was their basket design, where large amounts of plants were used. Many species of plants had a symbolic meaning for the Chinese. It significantly influenced the development of their floral design. For example, pear, peach, pine, and bamboo are associated with longevity in China (Belcher, 1998). There is also a seasonal association of flowering plants with four seasons. Spring is symbolized by a blooming Orchid or Magnolia; summer by a peony or Lotus; autumn by a chrysanthemum; and winter by the flowering of a white plum or bamboo (Koehn, 1952).

Buddhism was introduced to Japan in the middle of the 6th century AD by monks from Korea, who brought with them both faith and ritual practices. With the assistance of Prince Shōtoku, it was almost immediately well accepted by the Japanese. In particular, creating and offering flower arrangements to the Buddha was a traditional part of this religion; flower offerings were made by the monks themselves. Over time, the custom of using flower arrangements exclusively for religious purposes spread to other celebrations. At first, flower arrangements outside of the religion were prepared for titled persons and the wealthiest nobility. Later the arrangement of flowers became familiar to all Japanese regardless of social status. And already in the 16 th century in Japan, special flower contests were established (Belcher, 1998).

Until recently, every traditional Japanese home had at least one room with a tokonoma, a stylized alcove. Visitors to a Japanese house or inns of a Japanese hotel immediately notice a gazebo, the so-called "tokonoma" at one end of the main salon. The floor of the tokonoma was raised one step above the rest of the matted floor of this hall. One or more kakemono (hanging scroll) with drawings made by famous masters, or large copies of calligraphic hieroglyphs of some Chinese scientist or some other famous person hung on the wall of tokonoma. The floor of the tokonoma was mostly also matte with a fancy border. Special attention was paid to the choice of the pile that separated tokonoma from the neighboring niche, equipped with shelves called "chigaidana" and small cupboards called "fukurotodana". This wooden pile was usually made from a piece of uncut timber of a fancy shape or had the appearance of an ordinary untreated tree trunk. Some ornaments, a Figure 3 made of metal, wood or porcelain, mounted on a wooden stand and flower arrangement were placed before kakemonom. It gave the hall a magical atmosphere of softness and harmony (Katsumata, 2013).

In the course of many years of development, the art of flower arrangement, due to the combination of national traditions with the canons of Buddhism, has received a special coloration. Ikebana, as a Japanese flower arrangement, has become a hallmark of Japanese art. One of the oldest known books on flower arrangement was published in Japan in 1445. Now there are several schools of Japanese flower design, each of which has its own style, which varies from traditional to very creative. The Ikenobo school was founded in the middle of the 15th century. Then, over the years, other schools developed. The Ohara School and Sogetsu School appeared in the 20th century. They are better known in Europe. Eastern design traditions have always had a great influence on European and North American flower arrangement art (Belcher, 1998).

The Turkish-Persian cone-shaped design was of great importance in the evolution of European styles of cut flower arrangement of the Byzantine period (500-1453 AD). Such structures were tall, slender and narrowed to the top, and the container was usually made in the form of a bowl or urn. A spiral decorated with jewels ribbon was often fastened around such an arrangement of lilies, daisies, carnations, pine, grapes, and some other bright fruits. The great artists of that period left us a valuable legacy in paintings that perfectly captured this tradition. And at the beginning of the 17th century, the fashion for still-life paintings spread among European artists, as evidenced by their paintings with cut flowers (Figure 3). Among the still-life paintings of famous artists, there are paintings that depict bouquets arranged with fruits, butterflies, birds, and decorative vases. Fruits, birds, insects, and sometimes animal skins and carcasses were placed either in the flower arrangement itself or on the table next to it (Belcher, 1998).

The history of immortelles use as a separate direction of decorative art is still waiting for study. The following dried plants could be used: everlasting (Helichrysum Mill, nom. cons.), in particular, the sand immortelle (H. arenarium (L.) Moench,); gomphrena globosa (Gomphrena globosa L.); sea lavender, also known as limonium (Limonium Mill., nom. cons.); some species of ornamental amaranth (Amaranthus L.)); I unaria (Lunaria L.), etc. Plants with decorative seedboxes are very attractive. They are the following: nigella damascena (Nigella damascena), molucella (Molucella L.), etc., as well as numerous wild and cultivated cereals: lagurus (Lagurus ovatus L.), millet (Panicum L.,), wheat (Triticum L.), rye (Secale L.), barren oats or avens (Avena fatua L.), koeleria (Poa L.), etc.

Now immortelles are often replaced with artificial, in particular, plastic flowers. Plastic flowers cannot be approved either for aesthetic or environmental standards. The history of the art of making artificial ornamentals that imitate natural floral and ornamental plants is lost in the centuries. At least we can assume that it is commensurate with the history of ornamental plant cultivation. There is evidence (Sorokina, 2016) that as early as three thousand years BC, Egyptian women decorated themselves with artificial flowers. Later this art spread in Ancient Greece. In particular, Pliny the Elder reports that in 350 BC artificial flowers were imported to Greece from Egypt. Beautiful flowers made of porcelain and gold were produced in Ancient Greece and Ancient China. However, flowers were also made from clay, feathers, parchment, enamel on metal, and other materials, both expensive and cheap. 

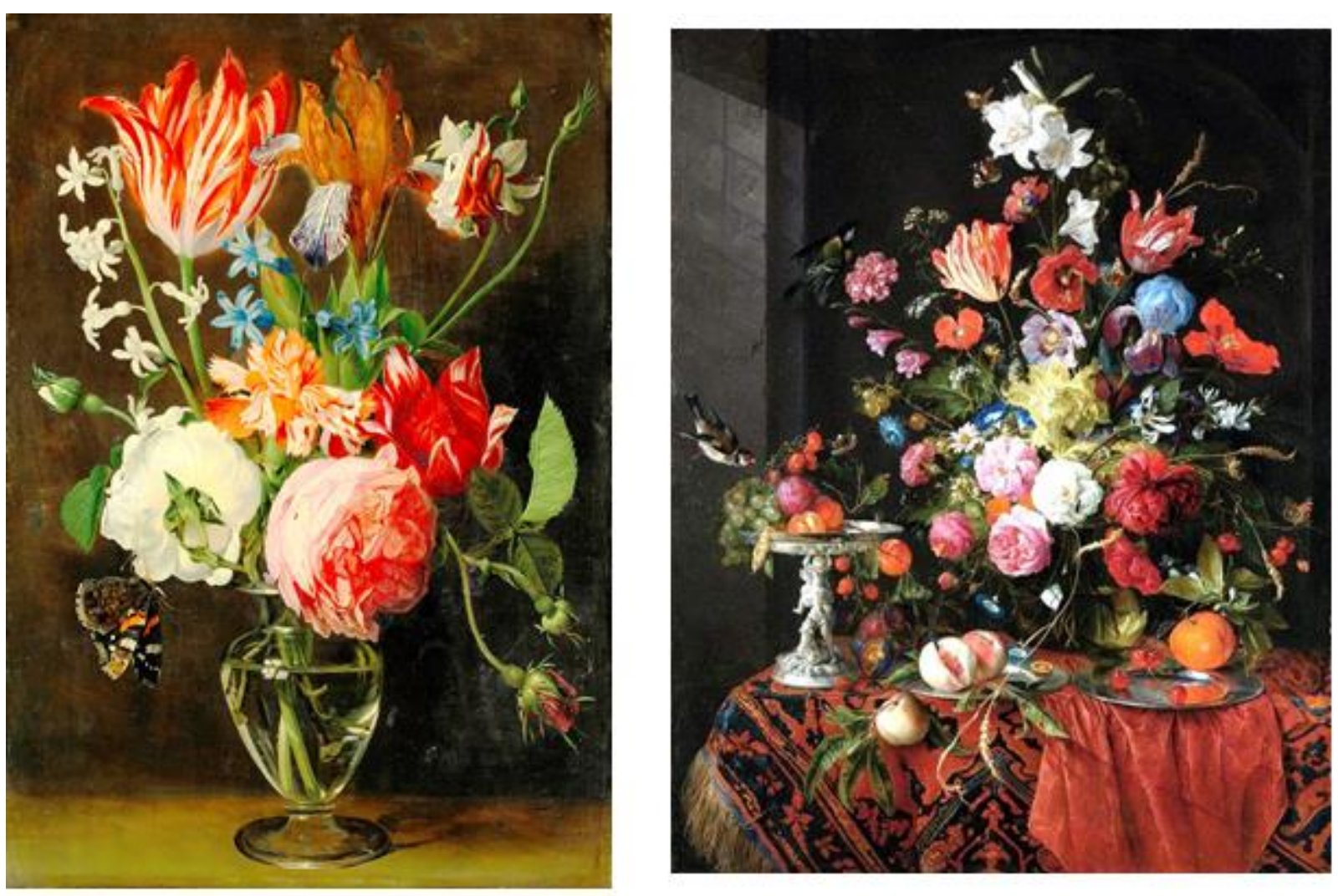

Figure 3. Still-life paintings with a bouquet of flowers: a - Daniel Seghers (1590-1661). Flowers in a glass vase with a red admiral butterfly. Available from: https://www.christies.com/lotfinder/Lot/daniel-seghers-antwerp-1590-1661-flowers-in-a-6217393details.aspx (Accessed 11 August 2019); b - Jan Davidsz de Heem (1606-1684). Flowers in a glass vase on a draped table, with a silver tazza, fruit, insects and birdsa. Available from: http://www.alaintruong.com/archives/2012/06/27/24593904.html (Accessed 11 September 2019).

About 1500 years ago, the Chinese started using silk to make artificial flowers. That technology was not popular, but the court ladies of the Imperial Palace were ordered to decorate their hair with silk flowers. Gradually, artificial silk flowers spread to wealthy families outside the Palace. With the opening of trade routes to Japan and Korea, the mentioned flowers gained popularity in these countries. Since the 12th century, Italian merchants brought artificial silk flowers to Europe, but soon the French masters surpassed the Italians and by the beginning of the 15th century, artificial flowers of French production were universally recognized as the best. At the court of Henry IV, there was even a position of court craftsman, who made flowers from the feathers of birds. After French revolution, many artisans fled to England, where they spread the fashion for artificial flowers, in particular, silk flowers, and English settlers brought it to America (Travers, 2014). For those who want to improve their skills in making paper flowers and mastering the art of arranging them in the style of origami-ikebana, the book by Benjamin John Coleman (Coleman, 2014) will be useful. In the book by Livia Cetti (Cetti, 2014), the famous craftswoman reveals until recently the secret methods of creating the most popular exquisite paper flowers, including such akin to live peonies, poppies, roses, hibiscus flowers, etc. She also offers examples of combining them in swags, garlands, small corsage bouquets and boutonnieres. The introduction of paper flowers should displace unwanted plastic flowers and greenery, as well as plastic floral tributes and other plastic attributes for the cemetery. In recent years they have flooded Ukraine, as well as most post-Soviet countries, especially on the eve of memorial days.

Further directions of landscape art development with various regional features are described in detail and illustrated in many fundamental monographs (Boults \& Chip, 2010; Cherny, 2014; Farrar, 2016; Haynes, 2013; Kosenko \& Pylypiuk, 2016; Likhachev, 1998; Nehuzhenko, 2011; Perry, 2010; Petrik, 2010; Rogers \& Hiss, 2016; Rubtsov, 1979; Tepe \& Markert, 2013). We send the interested reader to the mentioned resources. We will continue to discuss some aspects of using indoor plants.

\section{Indoor plants using}

Until recently, window sills were the preferred location for house plants. But the current diversity of indoor plants gives a rich choice for interior design not only for modern apartments, but also hotel lobbies, and various office spaces, wide staircases etc. Such additional factors as background color, angle of incidence and various lighting effects, well-chosen neighboring plants and the surrounding interior can demonstrate the best qualities of any plant in completely different ways. Special internal gardens allow a person to ignore the inevitable seasonal changes during the growing season and allow enjoying their natural beauty almost all year round. In such a garden, indoor plants are served not as simple accessories, but as a manifestation of the lifestyle of a gardener in love with nature (Martin, 2009).

The inner garden is particularly important for people with limited mobility. Small peperomia (Peperomia Ruiz \& Pavón) or aspidistra (Aspidistra lurida Ker Gawl.) on the windowsill can provide the person with special needs with a daily dose of nature (Martin, 2015). Properly decorated with indoor plants, the design of any room acquires live notes, and no one in such a room will feel deprived in communicating with nature.

Data on the use of indoor plants for air purification deserves a separate analysis (ElAziz et al., 2015; Jumeno \& Matsumoto, 2016; Geikhman, 1986). The fact is that indoor plants not only emit a huge amount of oxygen to the room in which they grow (although this function is the leading one), but also reduce the dustiness of premises, neutralize toxic impurities suspended in the air, making them safe for human lungs and skin. Besides, thanks to indoor plants, the air cleared of dust and pathogenic bacteria is saturated with moisture, volatile phyto-organic substances with abiotic impacts on a relatively large number of harmful microorganisms 
(bacteria, fungi, viruses, protozoa). Many other useful natural components are also released by green leaves (Geikhman, 1986; Tkachenko \& Kazarinova, 2008).

The scientific definition of phytodesign was introduced in the late 70s of the last century and received theoretical justification in the works of A. M. Grodzinskiy and his followers. The scientist defined it as a part of the general design with the introduction of indoor plants in the interiors of premises to perform aesthetic, environmental, sanitary and other useful functions (Grodzinskiy, 1979; Tarakanova \& Baklyskaya, 2014). For practical use of phytodesign, it was proposed to deliberately introduce medicinal and essential-oil-bearing tropical and subtropical plants with known medicinal properties into the interiors of offices, lobbies, waiting rooms etc. Soon, the creation of phytorecreations using a professionally selected range of plant species for the prevention and treatment of various, including infectious diseases, was separated into a special direction - medical phytodesign (Tarakanova \& Baklyskaya, 2014).

According to psychologists, home flowers, and especially daily care for them, have a calming effect on shattered nerves, regulate thinking, stimulate the brain and generate new creative ideas (Ferrante et al., 2015). Indoor plants are beneficial to man via different receptors: pleasing to the eye by beauty of form, pleasant smell and green color of the leaves have a calming effect on the nervous system, help to cope with a bad mood, and even severe stress.

Some plants with flowers and leaves of red shades, for example, Amaryllis (Amaryllis belladonna L.) or its relative in the family Amaryllidaceae J. St-Hil. - Hippeastrum (Hippeastrum x hortorum Maatsch.), hibiscus (Hibiscus rosa-sinensis L.) with dark red flowers, poinsettia (Euphorbia pulcherrima Willd. ex Klotzsch) and others raise the tone and increase activity. For overworked creative people, it is useful to spend at least a little time every day with floral and ornamental plants, admire them, take care of plants, and take pictures of them. If possible, it is desirable to allocate a separate room for relaxation, turning it into a small jungle and spends some time there, recuperating after a busy day or week (Opalko at al., 2019).

In recent decades, in parallel with the growing popularity of floral and ornamental plants, interest in the half-forgotten secret language of flowers is gradually beginning to revive. The traditional structure of the Japanese flower arrangement is based on an asymmetric, versatile triangle, outlined by three main points, usually rods, symbolizing heaven, earth, and man. Ikebana's strong symbolic and philosophical subtext (Kubo \& Schrempp, 2006) was not always clear to Europeans and was often modified according to the ethnic traditions of various communities (Sultanova, 2015). Founded in the 7th century in China, the art of arranging flowers was borrowed by the Japanese more than 600 years ago and developed by them to a modern aesthetic level called ikebana. It based on asymmetry, while European arrangements are characterized by a commitment to symmetry. The differences between these two styles of color arrangement are due to the different philosophical and religious backgrounds on which these styles were formed (Johnson, 2010). At the same time, they are quite changeable, as well as far from static forms of any art. Therefore, in our eclectic dynamic time, these two styles began to strongly influence each other and merge in a nonverbal way, combining different religious traditions (Moriyama \& Moriyama 1999).

The tradition of the language of flowers came from remote ages. This symbolic language was created by women of the East, who are dressed in a hijab and are limited to the strict framework of Islam. With closed faces, they were almost completely deprived of normal communication. So, all their feelings and all the shades of their mood were transferred to flowers (Gray, 2011). The language of flowers for the secret expression of feelings was widely used in France and Great Britain in the Victorian era. Flower dictionaries were published. European boys, girls, and many married ladies enthusiastically counted the number of petals, trying to unravel the "language" of each presented bouquet. Now, in an age of openness bordering on shamelessness, the fashion for the symbolic language of flowers is returning. Dictionaries of the language of flowers are published and sold out in different countries of the world (Contenson, 2009; Cruz, 2015; Diffenbaugh, 2014; Kirkby \& Diffenbaugh, 2011).

Well-groomed flower and ornamental plants located at the entrance and inside the premises are now becoming an important part of the image of a thriving company. A modern office is characterized not only by technical equipment and ergonomic furniture but also by a cozy and psychologically comfortable environment. At the same time, a carefully thought-out phytodesign of the office can enliven the strict interiors of workrooms and create a more favorable atmosphere for work. Before planning office greenery, it is necessary to carefully analyze the features of the microclimate of each zone, first of all on humidity and illumination, paying special attention to "risk zones". It can be shaded corners, places with drafts, space under the air conditioner, window sill over hot batteries, as well as places reserved for visitors, waiting for reception. All the mentioned can accidentally injure plants. According to the results of this analysis, it is possible to choose exactly those plants that will remain attractive throughout the year and will not require much effort to protect against pests and pathogens (Zachos, 2014) as well as quickly regenerate the effects of mechanical damage (Opalko et al., 2019).

It is very important to select drought-resistant plants for office premises taking into account the fact, that high-quality watering in the office is not always possible on weekends and holidays (Martin, 2015). It is equally important to choose plants that combine poly-modal aesthetic appeal with resistance against pathogens and pests. It is forbidden to use pesticides in offices, apartments, hotel lobbies, and other areas where people stay even for a short time. Therefore, the task of finding environmentally safe ways to increase the tolerance of indoor plants is extremely important (Opalko et al., 2019).

\section{Indoor plants as structural elements of phytocompositions}

Organizational polymorphism of floral and ornamental plants necessitates ordering their diversity. Based on the principles of the Linnean nomenclature of living organisms (Aldhebiani, 2018), the botanical classification is quite convenient for grouping wild plants, but it does not always meet the needs of producers, intermediaries (corporate buyers and/or sellers), as well as mass consumer of floral and ornamental products, and plant breeders. The vast majority of floral and ornamental plants belong to angiosperms, i.e. higher flowering plants. A small number of representatives of gymnosperms, ferns, as well as mosses and lichens, and even fungi are grown for the sake of a diversification of ornamental design possibilities (Brown, 2008). The need for their classification is caused not only by general cognitive interests but also motivated by purely pragmatic needs. After all, as a rule the buyer of a houseplant wants to know how durable it is, what kind of appearance its flowers will have, and how long it will preserve the product quality (actually the attractiveness for which the plant was purchased), etc. It is equally important to know how the selected plant propagates, which soil mixtures and containers to choose, how to water, what should be space between plants and lighting, and many other questions that arise from the manufacturer of floral and decorative products, the designer, as well as from the future amateur florist that purchased seeds, bulbs, seedlings or formed plants. It should be borne in mind that the needs of the area of indoor floriculture may vary in time and space depending on the preferences of consumers of different ages, different social, ethnic or religious groups, etc. 
However, the combining of plants into morphological groups is useful not only for the producer and consumer of floral and decorative products. It is also important for the botanist, geneticist, and breeder, physiologist or biotechnologist of plants to correctly place the plant under study in the appropriate morphological group. This information will contribute to effective research planning and successful implementation. It should be noted that the characteristics of some representatives of floral and decorative plants may correspond to the characteristics of two or more adjacent groups. Plants belonging to different botanical species, genera, and sometimes families or taxa of the highest level may be combined in the same group. Despite this, the classification provides tangible convenience for the flower-grower, the designer, and the breeder-geneticist.

In order to correctly select a strategy for improving the genotypes of each group of flower and ornamental plants and each individual crop, it is needed to know the features of sexual and asexual propagation methods. It is also important to take into consideration the levels of tolerance of the existing assortment with respect to biotic and abiotic factors of cultivated environment, unfavorable conditions of off-season cultivation in areas far from the natural habitat in particular, light and moisture deficiency and cooler environment, and also the levels of pathogens and pests tolerance.

Depending on the mentioned and many other approaches, different classifications can be based on different features of the origin, use, or distinctive features of indoor ornamental plants (Cook, 2012; Sibley, 2017; Sorokina, 2016; Vermeulen, 1999). According to their origin, they are divided into groups of plants from wet tropical forests (amaryllis, bromeliads, dieffenbachia, orchids, philodendrons, etc.); from savannas and prairies (asparagus, dracaena, pelargonium, tulips, ant other bulbous, individual cereals and some orchids); from deserts and semi-deserts (cactus, in particular astrophytums, gasteria, echinocactus, lampranthus, prickly pear, portulacaria and other succulents); plants of moderate climate (primroses, lilies of the valley, anemones).

Greenhouse plants that in our zone can reach normal development and wintering only in a greenhouse are divided into groups (Sorokina, 2016) depending on the need for temperature conditions in winter. They are the following: plants of cool greenhouses with a temperature of $3-6^{\circ} \mathrm{C}$ (fuchsias, pelargonium, laurel, camellia, citrus, crassula, dracaena, yucca and some palms); semiwarm greenhouses with a temperature of $8-15^{\circ} \mathrm{C}$ (joyweeds, coleus, cudweed, heliotrope, begonia, ferns); warm greenhouses with a winter temperature of $18-25^{\circ} \mathrm{C}$ (orchids, bromeliads, some ferns, in particular maidenhairs, as well as some Arecaceae, in particular, Chinese fan palm).

Potted plants can be disposable (winter gillyflower, cineraria) and reusable (azalea, amaryllis, hippeastrum, gloxinia, calla, cyclamen, evergreen trees and shrubs, succulents). According to the terms of finished products receiving plants can be divided into plants in autumn (amaryllis, primula, chrysanthemum); winter (azalea, hippeastrum, tufted airplant and most of bromelia, kalanchoe, camellia japonica, phalaenopsis, cyclamen); spring (anthurium, spikenard, primrose, peace lily, cineraria) and summer-flowering (begonia, fuchsia). Accordingly, there are seasonally flowering herbaceous plants (winter gillyflower, primrose obkonika, chrysanthemum, cyclamen, cineraria hybrid, etc.); bulbous and rhizomatous forcer plants (amaryllis, hyacinth, lily of the valley, lily regale, narcissus, tulip, etc.) and flowering shrubs (lilac, hydrangea, roses, etc.). At the same time, it should be noted that many of these and other plants can be encouraged to bloom at any time of the year thanks to special technologies (Sorokina, 2016).

The plants can be combined in separate groups: herbaceous plants (begonia rex, begonia maculata, begonia metallica, aspidistra, clivia, crinum lily); ferns (adiantum, nephrolepis, pteris); weeping and ramble evergreen plants (asparagus plumosus, asparagus Sprengeri, ivy, tradescantia, saxifraga, chlorophytum, cissus, pelargonium peltatum, philodendron, etc.); succulents (cacti — phyllocactus, epiphyllum, cereus, prickly pear, echinocactus, mammillaria, pereskia, as well as agave, aloe, etc.); trees and shrubs (ficus, laurel, lemon, palm, dracaena, cherry laurel, Japanese privet, tree aeonium, oleander, aralia, aucuba, camellia, azalea, etc.). Pelargonium can grow as a perennial herbaceous plant and semi-shrub, less often a shrub, sometimes succulent, and fuchsia hybrid - as erect and weeping shrubs. Separately, flower and ornamental plants are grouped into seedling plants and plants that are planted or sown directly into the ground. Some plants, in addition to attractive flowers, have original leaves, which can also be an interior decoration. This group includes pelargoniums with unusual leaves in shape and color, bromeliads, and many others (Sorokina, 2016).

Succulent pelargoniums, for example, South African species Pelargonium crassicaule L'hér. (Retief \& Bester, 2009) and some others (P. carnosum (L.) L'hér., P. cortusifolium L'hér., P. gibbosum (L.) L'hér.), are used for stylized interiors when creating bonsai-style composition (Harvey, 2014).

In large halls of successful companies, it is increasingly possible to see pools of different sizes, sometimes with fountains, and in offices aquariums with decorative fish and aquatic plants both directly in the water and next to artificial reservoirs. Among them, there are plants that live only in water (submerged and floating macrophytes), as well as plants that grow in places with excessive soil moisture (hydrophytes). A distinction is made between the species of fresh water, enriched with calcium carbonate (lot pondweed); species of desalinated sea and alkaline (rich in sulphates) water (rupees) and species requiring seawater (surfgrass). Elodea and some species of aponogeton, eelgrass, nuphar, echinodorus, cryptocorynes, sagittaria, etc. grow well in aquariums. Plants that float freely on the surface or in the water column (species of water fern and other Salviniaceae, elodea and other waterweed, Pontederiaceae, etc.) are defined as a separate group. Some of these families there are species, rooting in the soil. The spread of aquatic plants in indoor design has led to the fashion for indoor mini-basins (Sorokina, 2016). They are placed in the middle of the room in well-lit places, but not under direct sunlight. In such mini-reservoirs with a depth of five or more centimeters, floating plants quickly multiply and form a kind of "magic wilds on a plate", where water fern, water hyacinths, and water lettuce, floating moss, duckweed, etc. grow.

Regarding the specifics of aquadesign, there are decorative aquariums with a arbitrary and dynamic composition of plants and aquatic animals; biotope that imitate a certain biotope and Dutch aquariums - a kind of underwater gardens in which plants are planted very tightly and aquarium fish corresponding to these plants are selected. According to a special order, aqua designers can produce exclusive aquariums, as well as story aquariums, in particular "pseudo-sea" or avant-garde aquariums with multi-colored soil, unusual lighting, etc., and various fantastic unnatural accessories (Pankina \& Zakharova, 2011).

This is not a complete list of the used systems for indoor flower and ornamental plants. Approaches to the classification of phytoarrangement and its structural elements in interior design are no less diverse and no less contradictory (Trotska, 2012).

The already cited ideas of A. M. Grodzinskiy for distinguishing phytodesign as an independent direction of botany and design (Grodzinskiy, 1979) were developed in the works of his followers (Cherevchenko et al., 2013; Tarakanova \& Baklyskaya, 2014; Trotska, 2012). These works contain the response to the negatives caused by the scientific and technical revolution for the harmonization of the "man-nature" system, ergonomic approaches have developed in the design of the interior. They contribute to achieving the most comfortable stay of a person in it, taking into account the hygienic, socio-psychological, psychological, physiological and anthropometric aspects (Budarin \& Saprykina, 2016). 
In addition to medical phytodesign (Tarakanova \& Baklyskaya, 2014), there is an ecological phytodesign (Tsitsilin, 2003) with solitaire plants (dracaena, cypress, monstera, yew, palm, ficus, yucca, etc.); group phytocompositions, including an accent (mostly large) plant, supplemented with weeping forms and decorative-deciduous and beautifully-flowering plants (Pankina \& Zakharova, 2011). As a variety of group phytoarrangements, green walls of living plants are becoming increasingly popular and separate functional or intersubject zones; indoor gardens in containers with specially selected plants with different leaves in color, shape, and texture; hanging arrangements with weeping plants; florariums - landscapes with plants planted in a vessel made of glass or other transparent material, as well as green showcases, as a type of florarium placed at the window; tropicariums in the form of glass structures that combine an aquarium, florarium and terrarium. In a special room with regulated conditions, winter gardens are created. They combine the function of a park under the roof for short-term recreation during a break in production, as well as a wellness function in sanatoriums, dispensaries and for conducting cultural events in the palaces of culture and sports (Pankina \& Zakharova, 2011).

Many other materials have been published, because the issue of using ornamental garden plants in the design of modern interiors, such as small apartments and large estates, and various public spaces, is inexhaustible. Phytocompositions in the interior design must remain a work of art with a bioesthetic meaning.

\section{Conclusion}

The analysis of domestic and world publications was devoted to the evolution of perception in different cultures and epochs of the value of nature as a habitat environment and understanding of the historical antecedents of ornamental gardening, in particular, the new trends of Green Urbanism. It shows the need to introduce indoor plants in the interiors of residential and office premises in order to create a favorable atmosphere for work and leisure. The world experience of using ornamental garden plants testifies to the eternal desire of man to unite with nature, which is of particular importance in the conditions of progressive urbanization. Modern global trends of Green Urbanism are gaining special significance and relevance in Ukraine in connection with the aspirations of the Ukrainian public to integrate our country into the European community.

\section{Acknowledgement}

This study is partly based on the work supported by the National Dendrological Park "Sofiyivka", National Academy of Science of Ukraine (No 0119U002009). We are deeply grateful to Anatoly F. Balabak, Doctor of Sciences in Agriculture, the Professor of the Uman National University of Horticulture whose generous interest and useful advices were promoted our research.

\section{References}

Aldhebiani, A.Y. (2018). Species concept and speciation. Saudi Journal of Biological Sciences, 25(3), 437-440. DOI: https://doi.org/10.1016/j.sjbs.2017.04.013.

Aristov, N.Ja. (1866). Industry of ancient Russia. St. Petersburg. 335 p. (In Russian).

Baeyer, E. (2010). The development and history of horticulture. Eolss Publishers. 25 p.

Beatley, T. (2012). Green Urbanism learning from European cities. Washington; Covelo: Island press. 512 p.

Belcher, B. (1998). Creative flower arranging: Floral design for home and flower show. [Photo: Richard Moore; Illustr.: Denise Hoage]. Portland: Timber Press. 222 p.

Boults, E., Chip, S. (2010). Illustrated history of landscape design. John Wiley \& Sons. 275 p.

Bowler, L. (2016). A brief history of the use of flowers in Christian worship [online]. Anglican Historical Society Journal, $61,35-42$.

Budarin, E.L., \& Saprykina, N.A. (2016). Features of the principle of ergonomics in architecture and design of the modern housing. Ontology of designing, 6, 2(20), 205-215. DOI: https://doi.org/10.18287/2223-9537-2016-6-2-205-215. (In Russian).

Cetti, L. (2014). Exquisite Book of Paper Flower Transformations: Playing with Size, Shape, and Color to Create Spectacular Paper Arrangements. New York: Abrams. 176 p.

Cherevchenko, T.M., Denisyevskaya, N.A., Vachrushkin, V.S., Krupodorov D.V. (2013). Exposition of succulent plants in greenhouse at the N. N. Grishko National Botanical Gardens of National Academy of Sciences of Ukraine. Conservation of tropical and subtropical plants biodiversity: The papers of II international scientific conference and schools (Kharkiv, October, 7-10, 2013). Kharkiv: Tarasenko V.P. 18-26. (In Russian).

Cherny, B. (2014). Russian medieval gardens: the classification of experience [Handwritten monuments of Ancient Rus]. Moscow. Bukva. 5063 p. (In Russian).

Coleman, B.J. (2014). Origami ikebana: Create lifelike paper flower arrangements. Tokyo et al.: Tuttle Publishing. 353 p.

Contenson, E. (2009). The language of flowers. Paris: Archives et Culture. 70 p. (In French).

Cook, W. (2012). Indoor gardening: How to grow gorgeous gardens indoors with ease. Tck Publishing. 102 p.

Cruz, P.S. (2015). The language of flowers dictionary. Bloomington: Xlibris Corporation. 50 p.

Diffenbaugh, V. (2014). The language of flowers: [novel]. Moscow: Ripol Klassik. 317 p. (In Russian).

Dirr, M.A. (2009). Manual of woody landscape plants: their identification, ornamental characteristics, culture, propagation and uses. London: Stripes Publishing. 1325 p.

Easterlin, R.A. (1974). Does economic growth improve the human lot? Some empirical evidence. Nations and households in economic growth, 125, 89-125.

Easterlin, R.A. (2015). Happiness and economic growth: The evidence. [Eds.: W., Glatzer, L., Camfield, V., Møller, \& M., Rojas]. USC Dornsife Institute for New Economic Thinking. Working Paper, 14-03. 1-30.

ElAziz, N.G.A., Mahgoub, M.H., Mazhar, A.M.M., Farahat, V.V., Abouzeina, H.F. (2015) Potentiality of ornamental plants and woody trees as phytoremidators of pollutants in the air: A review. International Journal of ChemTech Research, 8(6), 468-482.

Farahani, L.M., Motamed, B., Jamei, E. (2016) Persian gardens: meanings, symbolism, and design. Landscape online, 46, 1-19. DOI: https://doi.org/ 10.3097/LO.201646.

Farrar, L. (2016). Gardens and gardeners of the ancient world: history, myth and archaeology. Oxford: Windgather Press. $411 \mathrm{p}$.

Ferrante, A., Trivellini, A., Scuderi, D., Romano, D., Vernieri, P. (2015). Post-production physiology and handling of ornamental potted plants. Postharvest Biology and Technology, 100, 99-108. DOI: https://doi.org/10.1016/j.postharvbio.2014.09.005.

Gasanov, Z. M., İskandarova, T. G. \& Bilmanli, A. ̇. (2014) Environmental conditions and use of fruit plants in landscaping of Gyandzy town. Contemporary horticulture, 2. Available from: http://journal.vniispk.ru/pdf/2014/2/28.pdf (Accessed 08 January 2020). (In Russian). 
Geikhman, L. Z. (1986). Aerophytptherapia. Kyiv. Naukova Dumka. 128 p. (In Russian).

Gray, S. (2011). The secret language of flowers [Illustr.: Sarah Perkins]. London: Ryland Peters and Small. 128 p.

Grodzinskiy, A. M. (1979). Phytodesign: problems and prospects UNESCO News. Newsletter, 9, 1-8. (In Russian).

Harvey, T. (2014). Succulent cultivars and hybrids - an introduction. Cactus and Succulent Journal, 86(5), 180-194. DOI: https://doi.org/10.2985/015.086.0508.

Haynes, G. (2013). Landscape and Garden Design: Lessons from History. Dunbeath, Caithness: Whittles Publishing. 201 p.

Ingels, J.E. (2010). Ornamental horticulture: science, operations, and management [Fourth Edition]. Delmar: Cengage Learning. $712 \mathrm{p}$.

Janick, J. (2002). History of Asian horticultural technology. Acta Horticulturae, 620, 19-32. DOI: https://doi.org/10.17660/ActaHortic.2003.620.1.

Janick, J. (2007) The origins of horticultural technology and science. Acta Horticulturae, 759, 41-60. DOI: https://doi.org/10.17660/ActaHortic.2007.759.3.

Janick, J. (2014) Horticulture and art. Horticulture: Plants for people and places [Eds.: Geoffrey R. Dixon \& David E. Aldous]. Trilogy. Heidelberg: Springer Science and Business Media. Vol. 3: Social Horticulture, Ch. 36, 1197-1223. DOI: https://doi.org/10.1007/978-94-017-8560-0_36.

Johnson, N.B. (2010). Religion, spirit, and the idea of garden. Religious Studies Review, 36(1), 1-14. DOI: https://doi.org/10.1111/j.1748-0922.2010.01395.x.

Jumeno, D. \& Matsumoto, H. (2016). The effects of indoor foliage plants on perceived air quality, mood, attention, and productivity. Journal of Civil Engineering and Architecture Research, 3(4), 1359-1370.

Katsumata, S. (2013). Tokonoma - the eye of the Japanese parlour. Gleams from Japan. London \& New York: Routledge Revivals. 9-15.

Kirkby, M., \& Diffenbaugh, V. (2011). A Victorian flower dictionary: The language of flowers companion. New York: The Random House Publishing Group. 192 p.

Koehn, A. (1952). Chinese flower symbolism. Monumenta Nipponica, 8(1/2), 121-146. DOI: https://doi.org/10.2307/2383008.

Kolesnikov, A. I. (1974). Decorative dendrology. Moscow. Forestry Industry. 1974. pp. 615. (In Russian).

Kosenko, I.S. \& Pylypiuk, V.V. (2016). Sofiyivka. National dendrological park: Photo albums. Kyiv: Palyvoda A.V. 275 p. (In Ukrainian).

Kubo, K., \& Schrempp, E. (2006). Keiko's ikebana: A Contemporary Approach to the Traditional Japanese art of Flower Arranging [Photographer: Erich Schrempp]. North Clarendon: Tuttle publishing. 128 p.

Likhachev, D.S. (1998). Poetry gardens: to the semantics of landscaping style garden as text. Moscow. Soglasie. 356 p. (In Russian).

Lipovetsky, G. (1993). L'ère du vide: Essais sur l'individualisme contemporain. Paris: Gallimard, 328 p. (in French).

Martin, T. (2009). Once upon a windowsill: A history of indoor plants. Portland: Timber Press. $312 \mathrm{p}$.

Martin, T. (2015). The indestructible houseplant: 200 beautiful plants that everyone can grow [Photo.: Kindra Clineff]. Portland: Timber Press. 289 p.

McBride, M. (2010). Money, happiness, and aspirations: An experimental study. Journal of economic behavior \& organization, 74(3), 262-276. DOI: https://doi.org/10.1016/j.jebo.2010.03.002.

McDonald, J.A. (2018). Influences of Egyptian lotus symbolism and ritualistic practices on sacral tree worship in the Fertile Crescent from 1500 BCE to 200 CE. Religions, 9(9), 256, 27. DOI: https://doi.org/10.3390/rel9090256.

Moriyama, Mar. \& Moriyama, Meg. (2000). A comparison between asymmetric Japanese ikebana and symmetric Western flower arrangement. Forma-Tokyo, 14(4), 355-361.

Nehuzhenko, N.A. (2011). Basics of landscape design and landscape architecture: [Textbook, 2nd ed., Corrected. and add.]. St. Petersburg. Publishing House "Piter". 192 p. (In Russian).

Nonaka, N. (2017). Renaissance porticoes and painted pergolas: Nature and culture in early modern Italy. Routledge. $226 \mathrm{p}$.

Opalko, A.I., Weisfeld, L.I., Bekuzarova, S.A., Burakov, A.E., Opalko, O.A., \& Tatarinov, F.A. (2019). Tolerance improvement of indoor plants. Temperate Horticulture for Sustainable Development and Environment. Ecological aspects. [Eds.: Larissa I. Weisfeld, Anatoly I. Opalko, \& Sarra A. Bekuzarova.]. Oakville; Waretown: Apple Academic Press, Ch. 8, 119-149.

Pakhomov, O.Y., Opanasenko, V.F., Kabar, A.M., \& Rusets'Ka, L.L. (2008). Results of lignosa and shrubs introduction in arboretum of botanical garden of the Dnipropetrovsk university. Biosystems Diversity, 2(16), 131-136. DOI: https://doi.org/10.15421/010859. (In Ukrainian).

Pankina, M.V. \& Zakharova, S. V. (2011). Environmental Design: textbook. Biysk: Biya. 188 p.

Perry, R.C. (2010). Landscape plants for California gardens: An illustrated reference of plants for California landscapes. Claremont: Land Design Publishing. 652 p.

Petrik, V.V. (2010). The history of landscape art: the text of the lectures. Arkhangelsk: Northern (Arctic) Federal University. 243 p. (In Russian).

Pomerantz, G.S. \& Mirkin, Z.A. (2012). The sunsets and dawns civilizations. Social Sciences and the present, 2, 155-160. (In Russian).

Retief, E., \& Bester, S. P. (2009). Pelargonium crassicaule L'Hér (Geraniaceae), 1-4. Available from: https://www.researchgate.net/publication/251236262 (Accessed 08 January 2020). (In Russian).

Rogers, E.B. \& Hiss, T. (2016). Green metropolis: The extraordinary landscapes of New York City as nature, history, and design. New York. Alfred A. Knopf. 240 p.

Rubtsov, L.I. (1979). Design of gardens and parks. Moscow: Stroyizdat. 184 p. (In Russian).

Seneta, W. \& Dolatowski, J. (2012). Dendrologia. Warszawa: Wydawnictwo Naukowe PWN. 544 s. (In Polish).

Sibley, E. (2017). Urban botanics: An indoor plant guide for modern gardeners. Aurum Press. $160 \mathrm{p}$.

Someh, M.F., Basiri, M., \& Azim, A.Z. (2014). The role of green roofs in urban sustainability. European Scientific Journal (Special edition), 2, 69-75.

Sorokina, S.V. (2016). The commodity science of flowers: a textbook. Kharkiv: Kharkiv State University of Food Technology and Trade. (CD-ROM). 399 p. (In Ukrainian).

Sultanova, G. (2015). Ikebana in Russian. Moscow: Litres. 169 p. (In Russian).

Takei, J. \& Keane, M.P. (2001). Sakuteiki: Visions of the Japanese garden: A modern translation of Japan's gardening classic (Tuttle classics). Clarendon: Tuttle Publishing. 256 p. 
Tarakanova, K.V. \& Baklyskaya, L.E (2014). Fitodesign in the interior and its impact on human activity. The new Ideas of New Century. The Fourteenth International Scientific Conference Proceedings. Khabarovsk: Pacific National University Press,. Vol. 2, 235239. (In Russian).

Tepe, E. \& Markert, P. (2013). The edible landscape: Creating a beautiful and bountiful garden with vegetables, fruits and flowers [Ed.: Melinda Keefe]. Minneapolis. Voyageur Press. 160 p.

Thommen, L. (2012) An environmental history of Ancient Greece and Rome. Cambridge; New York: Cambridge University Press. 186 p.

Tkachenko K.G. \& Kazarinova N.V. (2008) Medical phytodesign - using plants into interior and prophylactics infectious diseases. Belgorod State University Scientific Bulletin: Natural sciences,3(43), 6, 53-59. (In Russian).

Tomlinson, H. (2004). The complete book of bonsai. London: Dorling Kindersley. 224 p.

Travers, Ph. (2014). Artificial flowers - a brief history. Artificial Plants \& Trees. Available from: http://journal.vniispk.ru/pdf/2014/2/28.pdf (Accessed 08 January 2020).

Trotska, O.S. (2012). Bioesthetic characteristic of floral elements in interior design. Scientific Issues of Ternopil Volodymyr Hnatiuk National Pedagogical University. Series: Art Studies, 3, 234-238. (In Ukrainian).

Tsitsilin, A. N. (2003). Ecological phytodesign is an innovative technology for the use of plants. Unconventional Natural Resources, Innovative Technologies and Products, 10, 31.

Vermeulen, N. (1999). Encyclopedia of house plant [Ed.: Richard Rosenfleld]. REBO production Routledge. 321 p.

Wang, H., Cheng, Z., \& Smyth, R. ( 2018). Consumption and happiness. The Journal of Development Studies, 55(1), 120-136. DOI: https://doi.org/10.1080/00220388.2017.1371294.

Yakandawala, K. (2016). Strategic analysis for the aquatic cut flower industry. Acta Horticulturae, 1131, 105-110. DOI: https://doi.org/10.17660/ActaHortic.2016.1131.14.

Zachos, E. (2014). Growing healthy indoor plants: Choose the right plant, water wisely and control pests [Eds.: Sarah Guare and Carleen Madigan]. North Adams: Storey Publishing. 129 p.

\section{Citation:}

Kosenko, I.S., Hrabovyi, V.M., Opalko, O.A., Muzyka, H.I., Opalko A.I. (2020). Current trends in Green Urbanism and peculiarities of multifunctional complexes, hotels and offices greening. Ukrainian Journal of Ecology, 1011), 226-236.

(cc) EY This work is licensed under a Creative Commons Attribution 4.0. License 